\title{
Focus on Field in an Advanced Reading Classroom
}

\section{Ayumi Inako \\ Kobe City University of Foreign Studies}

\section{Reference Data:}

Inako, A. (2019). Focus on field in an advanced reading classroom. In P. Clements, A. Krause, \& P. Bennett (Eds.), Diversity and inclusion. Tokyo: JALT.

What can a reading classroom provide for advanced English learners beyond input into grammar and vocabulary? The author proposes a focus on field-the nature of the social action realized in the text-as well as using the scale of semantic gravity-the degree to which the meanings of the text relate to its context. Many reading materials contain multiple fields, which can cause difficulty for students in tracking their content. A case study of a text on the topic of solar storms employs the methodology of Legitimation Code Theory (LCT), whereby an external language for description is created for the specific research purpose. Analysis from the perspective of semantic gravity helps identify where shifts in the field of the text occur, enabling the teacher to guide the students in their reading as the text unfolds. The author concludes by discussing the applicability of this method.

上級英語学習者向けの読解授業が文法と語彙のインプット以外に提供できるものは何だろうか。本稿では、テクストによ って具現化される社会的活動の性質を表す活動領域 (field) に焦点を当てるとともに、テクストの意味が分脈と関係する度合 いを示す意味的重力 (semantic gravity)の概念を使用することを提案する。多くの読解教材には複数の活動領域が含まれ、 学習者にとつて内容の把握が難しくなる要因となっている。このケーススタディでは、「太陽嵐」に関する読解テキストを取り上 げ、正当化コード理論 (Legitimation Code Theory一LCT)の方法論に基づいて、本研究に特定の目的に合わせた外的記述言 語 (external language of description)を作成する。分析によって、意味的重力の観点がテキストの展開とともに活動領域の移 行が起きている場所の特定に役立つことが明らかになる。結論として、この方法の応用可能性を議論する。

eaching reading to advanced learners of English can be a challenge. Students are expected to be familiar with the relevant grammar, and if they learn vocabulary in advance, they should be capable of discussing the content in the classroom. This is particularly the case in university reading classrooms for students majoring in international relations, where students are highly motivated to improve their English skills. Teachers tend to expect the students to have read the text, looked up unknown words in the dictionary, and have understood it in advance, and therefore be ready for class discussion. However, it often turns out in class that in spite of their preparation, students have not fully understood the content of the text, as revealed by incorrect answers on reading comprehension exercises or misinformed discussion when it comes to group work.

This is particularly the case in the tertiary reading classroom, where students are exposed to reading materials incorporating different varieties including science, social sciences, and humanities of academic content. Moreover, as will be illustrated in this paper, many such materials are multidisciplinary, in other words the content shifts from one area to another, from discussions using everyday language to scientific definitions and technological expositions. This can confuse readers and make it hard for them to track the developing topic. Reading classes are supposed to provide students with the analytical skills to guide their own reading as the text unfolds, pinpointing shifts in content as they occur.

To this end, I propose using two theoretical concepts that can help guide students' understanding of the text in the reading classroom. The first is the linguistic concept of field, which in the framework of systemic functional linguistics (SFL) refers to that aspect of the context concerning the nature of the social action (see below). The other concept, deriving from the sociological perspective of Legitimation Code Theory ${ }^{1}(\mathrm{LCT})$, is that of semantic gravity, focusing on the degree to which the meanings of the text relate to its context (Maton, in press). Dialogue over the last decade on the language of education has established that the two theories of SFL and LCT offer complementary perspectives on education and knowledge structure (Martin \& Maton, 2017; Maton \& Doran, 2017). This is exemplified by a number of large-scale research projects on discourse for building knowledge including work on academic subjects such as history (Matruglio, Maton, \& 
Martin, 2013), teacher training in biology (Macnaught, Maton, Martin, \& Matruglio, 2013), and critical thinking (Szenes, Talakaratna, \& Maton, 2015).

Although many of the research projects are based on extensive data sets including "teaching texts, student assessments and classroom practice" (Maton, 2013, p. 13), in the current paper I take a case-study approach, focusing specifically on one particular passage from the reading material $I$ used in some of the classes I teach. The aim is to explore how we can apply these theoretical concepts from linguistics and sociology at the level of daily teaching practice so that the particular students we teach in each class can benefit from such an approach.

In the following sections, I begin by introducing the key theoretical concepts of field in SFL and semantic gravity in LCT. This is followed by a brief description of the specific text and the class in which it was used. The analysis of the text from these two perspectives enables the teacher to guide students through the text as it unfolds, shifting from one field to another. Based on this case study, I discuss how an analysis from the two perspectives of field and semantic gravity can illuminate the reading process and hence provide practical suggestions for ways in which advanced learners of English can gain more from the reading classroom.

\section{Conceptualizing Field and Semantic Gravity}

This section provides a more detailed introduction to the key complementary concepts employed in this study - field and semantic gravity — and how they are used to guide students in their reading of a specific text.

\section{Field in SFL: Categorical Understanding of Knowledge}

SFL conceptualizes language as providing resources for meaning-making as realized in social practice. In SFL, the concept of field is situated in relation to two layers of context (Martin \& Rose, 2008). The broader layer of context is known as genre, or "staged, goaloriented social process," realized by a more specific layer of context known as register, or "context of situation," defined in terms of three dimensions "realized by particular functional dimension[s] of language" (Martin \& Rose, 2008). One of them, field, or the nature of the social action that is taking place, has been of interest in the area of educational linguistics. Martin (1992) provides a taxonomy of fields that constitute various social and educational practices (Figure 1). Here, different kinds of fields are schematized on the scale between "common sense" and "uncommon sense."

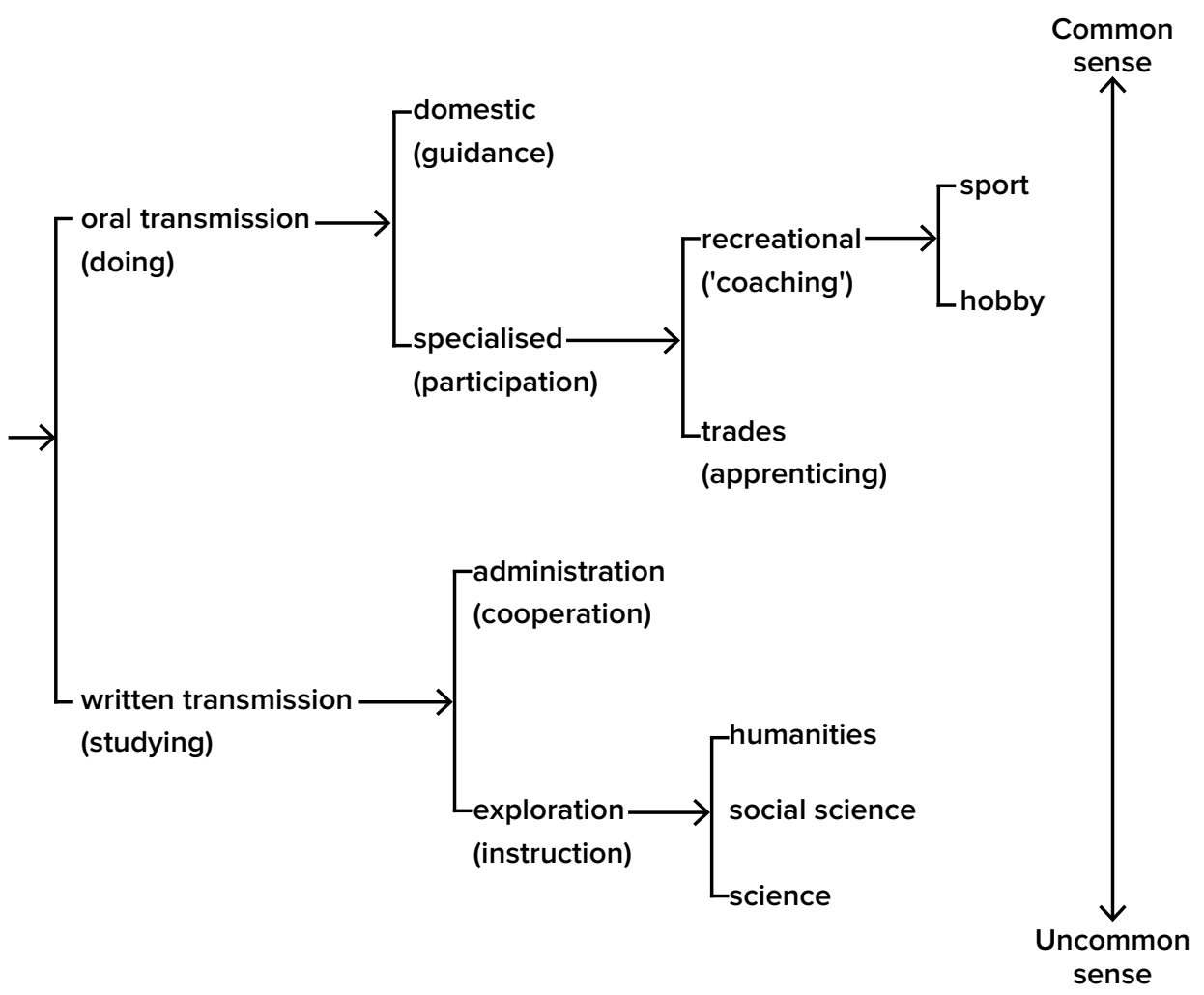

Figure 1. A provisional classification of field (Martin, 1992, p. 544).

This kind of taxonomy can provide a useful schema for categorizing the different kinds of knowledge realized in reading materials such as those examined in the present study. For instance, when we find in the text expressions such as read newspapers or start cooking breakfast, we can assume that they constitute a relatively common-sense field. On the other hand, if we encounter expressions such as massive eruption on the surface of the sun and the matter collided with our planet's magnetic field, it is more likely that we are dealing with the uncommon-sense field of science. However, it is not the 
goal of the reading classroom to classify the content of the text into different categories of knowledge as such. A detailed linguistic schematization may distract the students' attention from tracking content of the text as it unfolds for the sake of classifying each bit of content into distinct categories. A more fuzzy perspective in terms of relative degrees of a feature may be more useful, and this is where the concept of semantic gravity comes in.

\section{Semantic Gravity in LCT: Capturing the Relationship Between} Meaning and the Real-Life Context

LCT is a sociological theory, which has been developed into a practical framework for understanding knowledge building. LCT offers a number of dimensions, or codes, that can be used as a "conceptual toolkit" (Maton, 2014, p. 15). One of these tools is semantic gravity (SG), defined as "the degree to which meaning is related to its context" (p. 110). "The stronger the semantic gravity (SG+), the more meaning is dependent on its context; the weaker the semantic gravity (SG-), the less dependent meaning is on its context" (Maton, in press, p. 2).

In LCT, this seemingly simple conceptualization is complemented by a "translation device" (Maton \& Chen, 2016) consisting of the external language of description that each researcher creates depending on the purpose of research. The idea originated from Bernstein's (2000) distinction between an internal language of description and an external language of description. The former focuses on a theory and how theoretical concepts are interrelated; the latter goes beyond to how these concepts relate to real-life practices. For example, in this study, Martin's (1992) classification of fields and the LCT concept of semantic gravity constitute the internal language of description. An external language of description, on the other hand, is intended to focus on a specific research purpose, for instance, understanding a specific reading text in an English class. Maton and Chen (2016) discussed that these two perspectives allow for new or unexpected information to emerge from the data, just like having two types of lenses in a camera that can be adjusted depending on how much detail is needed for the purpose of the research. Such flexibility is useful for applying to classroom practice in which we technically deal with a different text in each class.

\section{Methodology: Case Study}

The case study examines a reading text entitled "Solar Storms" from an advanced-level textbook Active Skills for Reading 4 (Anderson, 2014). I used this textbook in 2017 in two classes of 42 students each at one of the universities where I teach, which is a relatively highly-ranked public university that requires, according to Benesse (n. d.), 85-88 percent in the National Center Test for University Admission to enter. The students are international relations majors, have a relatively high level of English competence, and are highly motivated to improve their English as well as to master specialized knowledge.

This textbook is designed to foster reading fluency, and the related classroom activities involved students completing reading comprehension exercises, and engaging in critical discussion. Most of the passages in the textbook are designed to be easily accessible to students, but I anticipated that the particular text selected for this case study would be more difficult, as it deals with multiple fields, both everyday and scientific. In class, I directed the students' attention to this aspect, but they still had difficulty in keeping track of the content as the text unfolded. I realized that a greater focus on the unfolding of the text was needed in order to more effectively guide the students, which is why I decided to analyze the same text from the perspective of semantic gravity.

In LCT methodology, creating an external language of description is part of the analysis itself. Narrowing down the kinds of meaning relevant to the research purpose is like adjusting various lenses on a camera to focus on a particular target. The external language of description on which the current analysis was based was developed via an exploratory process, as presented in the next section.

\section{Analysis}

\section{The External Language of Description}

An external language of description was created, using the study reported in Georgiou, Maton, and Sharma (2014) as a model, to analyze the degrees of semantic gravity in the text "Solar Storm," as shown in Figure 2.

For this particular text, it was useful to classify semantic gravity into four degrees from the perspective of field. The strongest degree of semantic gravity $(S G++)$, refers to meanings that concern tangible, down-to-earth daily events such as reading newspapers and cooking breakfast. A weaker degree of semantic gravity ( $(\mathrm{G}+$ ) concerns meanings related to more general aspects of modern society, for example, professional life, such as pilots landing at many airfields. The degree of semantic gravity becomes even weaker (SG -) when the meanings relate to more abstract, less tangible contexts, as for example in the realm of modern technology, such as communications satellites orbiting over the equator. The weakest degree of semantic gravity (SG - -) refers to scientific meanings whereby things and events are defined and interpreted based on a set of universal 
scientific principles. This includes instances such as the enormous plasma eruptions known as solar flares.

\begin{tabular}{|c|c|c|c|}
\hline $\begin{array}{l}\text { Semantic } \\
\text { gravity }\end{array}$ & $\begin{array}{l}\text { Coding } \\
\text { category }\end{array}$ & Description of content coded & Example from text extract \\
\hline \multirow[t]{4}{*}{ weaker } & SG - - & $\begin{array}{l}\text { interpretation of (possible) } \\
\text { events from a general, scientific } \\
\text { viewpoint }\end{array}$ & $\begin{array}{l}\text { Solar storms disrupt the } \\
\text { ionosphere. }\end{array}$ \\
\hline & SG - & $\begin{array}{l}\text { general, technological aspects } \\
\text { of (possible) events specific to } \\
\text { modern society }\end{array}$ & $\begin{array}{l}\text {... shortwave radio } \\
\text { signals bouncing off } \\
\text { the ionosphere to } \\
\text { communicate... }\end{array}$ \\
\hline & $\mathrm{SG}+$ & $\begin{array}{l}\text { professional aspects of } \\
\text { (possible) events in modern } \\
\text { human life }\end{array}$ & $\begin{array}{l}\text {... planes flying these polar } \\
\text { routes have to be diverted }\end{array}$ \\
\hline & $\mathrm{SG}++$ & $\begin{array}{l}\text { local, everyday aspects } \\
\text { of (possible) events in } \\
\text { contemporary human life }\end{array}$ & $\begin{array}{l}\text { In the eastern United } \\
\text { States, people were able to } \\
\text { read newspapers outside... }\end{array}$ \\
\hline
\end{tabular}

Figure 2. External language of description.

Based on this external language of description, it is now possible to examine the shifts in semantic gravity through the unfolding of the text and to identify where careful guidance is needed in order to prevent students from getting lost.

\section{SG Shift With Flow}

One initial difficulty $\mathrm{I}$ anticipated when preparing to teach this text was the shift of fields from everyday to scientific in paragraphs 1 and 2 in Extract 1. The text opens with an anecdotal recount of a solar storm event, beginning from the personal perspective of the astronomer, then expands its geographical scope to different parts of the world. Then, paragraph 2 repackages the event and interprets it from a universal scientific viewpoint.

\section{Extract 1}

[1] In 1859, an amateur astronomer Richard Carrington climbed the stairs to his private observatory near London.... He was looking at sunspots ... Suddenly, two patches of white light appeared around one sunspot. Before dawn the next day, ... [in] the eastern United States, people were able to read newspapers outside in the middle of the night....

[2] What Carrington had observed was a solar superstorm. A massive eruption on the surface of the sun sent billions of tons of electrical and magnetic matter hurtling through space. (Anderson, 2014, p. 135)

In terms of semantic gravity, there is a sharp shift between these two paragraphs, so that the first paragraph would be marked SG ++, and the second paragraph SG- - .

In the occurrence of such semantic shifts, however, the text often exhibits a strong semantic flow, providing some wording in the text that signals the "connectedness between consecutive points" of the shift (Maton, 2013, p. 19). For instance, in the above example, the first sentence of the second paragraph begins with the summarizing expression What Carrington had observed, which is then scientifically defined and explicated. Packaging the meaning expressed in previous text as the starting point for a new clause is a grammatical feature typical of scientific discourse (Halliday, 2004), and thus constitutes a flow, indicating that a shift is occurring in terms of field, i.e., from everyday to scientific, as well as in terms of semantic gravity.

Different kinds of resources can function as a flow, as in Extract 2.

\section{Extract 2}

He was looking at sunspots-areas of the sun that appear darker because they are slightly cooler than the surrounding areas. Suddenly, two patches of white light appeared around one sunspot. (Anderson, 2014, p. 135)

Here the dash (-) indicates that what follows it is a scientific definition, manifesting very weak semantic gravity. Then, in the next sentence, the marked theme suddenly increases the semantic gravity again by reverting to the personal experience of the astronomer. In these cases, the dash and suddenly connect the consecutive points in a shift in semantic gravity. 
Once the instructor is aware of the shift of semantic gravity as well as what functions as flow, it is not very difficult to draw students' attention to this. However, there are cases in which semantic gravity shifts sharply without such flows. In these cases, more careful guidance is needed.

\section{SG Shift Without Flow}

In the text "Solar Storm," one instance of semantic gravity shift without such flow can be found in the sixth paragraph, which deals with the possible risks from future solar storms, as shown in Extract 3.

\section{Extract 3}

A Carrington-class superstorm ... But even much smaller storms can cause considerable damage, especially as humans become increasingly dependent on technology deployed in space. Solar storms disrupt the ionosphere. This is the layer of Earth's atmosphere where auroras occur, a hundred kilometers above the Earth's surface. The pilots of the nearly 10,000 flights flying over the Arctic each year rely on shortwave radio signals bouncing off the ionosphere to communicate in an area beyond the range of communications satellites orbiting over the equator. When space weather disrupts shortwave communications, planes flying these polar routes have to be diverted.... (Anderson, 2014, p. 136)

Here, the third and fourth sentences exhibit very weak semantic gravity in discussing the general scientific mechanism whereby a solar storm can disrupt the ionosphere. The fifth sentence, however, begins with the noun group The pilots without any flow that indicates the strengthening of semantic gravity. This may cause readers to lose track of the content before they read the following two sentences and are able to grasp how the mention of pilots is relevant in discussing the potential damage from solar storms. There is also the potential here for readers to get lost in less relevant information such as where auroras occur, 11,000 flights, and orbiting over the equator. Classroom instruction should also help students keep on track with the text in spite of such distractors.

\section{Discussion}

Careful guidance not only helps students understand this particular text but also helps raise their general awareness of semantic gravity and how it shifts within one text, so that they can apply it in their future reading. As cited above, literature also stresses the importance of "explicit guidance" (Macnaught et al., 2013, p. 62) in allowing students to build awareness. The longitudinal teacher training project reported in Macnaught et al. (2013) adopted a structured approach by using Rothery's (1994) teaching and learning cycle, to enable the participant teachers to use the concepts in their biology instruction. On the other hand, Blackie (2014) used them to reflect upon her own chemistry instruction.

Likewise, semantic gravity can be incorporated in university reading classrooms in various ways. In preparing for classes, teachers can identify parts of the text where students may get lost and prepare extra questions to confirm their understanding or give extra instruction in the classroom. Extra slides illustrating the semantic profile in the form of a concept map can be prepared and shown in the class; the term semantic gravity may be replaced by more accessible expressions such as scale between general and specific. As students become more familiar, they may work in groups to create their own maps, so that students can develop their awareness in this area of meaning as part of their reading strategies.

\section{Conclusion}

I have been unable to collect data to support the effectiveness of this approach in improving students' reading skills. Although student reactions in class and their overall comments on the course suggest a positive evaluation, it would be a good idea to research students' perceptions through questionnaires or examine the effectiveness of the approach using something like standardized test results. The content of reading materials to which students are exposed is often drawn from a number of fields, which may make it difficult for students to track the content as fields shift in the unfolding of the text. This case study on teaching reading to advanced English learners at university level has proposed focusing on the variable of field. The conceptual tool of semantic gravity has been shown to offer an accessible means for tracking those shifts in field. Sometimes, linguistic or punctuation flows help readers keep track of those shifts, but even without such flows, employing the semantic gravity scale has been found helpful in guiding students through the reading process.

In this paper, analysis has been based on an external language of description specifically created for this research purpose. However, the overarching research principle, consisting of the simple and highly abstract conceptualization of semantic gravity, is applicable to any other reading text of any other level in guiding the process of creating a relevant external language. Further research may help us to understand 
how LCT can be applied to reading classrooms of different levels. This increased understanding will allow improved teaching practices that equip students with new strategies for approaching knowledge manifested in reading texts.

Note

1. According to Maton (2016), Legitimation Code Theory needs to be always capitalized, for being "an explanatory framework or conceptual toolkit, rather than a meta-theory or any specific substansive account generated by enacting concepts from LCT" (p. 240)

\section{Bio Data}

Ayumi Inako is a teacher and linguist with a PhD from the University of Technology, Sydney. She is interested in exploring how to apply discourse analysis to improve language and communication skills. <ayumimv@gmail.com>

\section{References}

Anderson, N. J. (2014). Active skills for reading 4. Boston, MA: Heinle Cengage Learning. Benesse. (n. d.). Manavision. Retrieved February 25, 2019, from https://manabi.benesse.ne.jp/ daigaku/school/2200/hensachi/index.html

Blackie, M. A. L. (2014). Creating semantic waves: Using Legitimation Code Theory as a tool to aid the teaching of chemistry. Chemistry Education Research and Practice, 15, 462-469.

Georgiou, H., Maton, K., \& Sharma, M. (2014). Recovering knowledge for science education research: Exploring the "Icarus effect" in student work. Canadian Journal of Science, Mathematics, and Technology Education, 14(3), 252-268. https://doi.org/10.1080/14926156.2014.935526

Halliday, M. A. K. (2004). Language and knowledge: The unpacking of text (1998). In J. J. Webster (Ed.), The language of science (pp. 24-48). London, England: Continuum.

Macnaught, L., Maton, K., Martin, J. R., \& Matruglio, E. (2013). Jointly constructing semantic waves: Implications for teacher training. Linguistics and Education, 24, 50-63. https://doi.org/10.1016/j.linged.2012.11.008

Martin, J. R., \& Maton, K. (2017). Systemic functional linguistics and Legitimation Code Theory on education: Rethinking field and knowledge structure. Onomázein, Número Especial LSF y TCL sobre educación y conocimiento, 12-45. https://doi.org/10.7764/onomazein.sfl.02

Maton, K. (2013). Making semantic waves: A key to cumulative knowledge-building. Linguistics and Education, 24(1), 8-22. https://doi.org/10.1016/j.linged.2012.11.005
Maton, K. (2014). Knowledge and knowers: Towards a realist sociology of education. London, England: Routledge.

Maton, K. (2016). Starting points: Resources and architectural glossary. In K. Maton, S. Hood, \& S. Shay (Eds.), Knowledge-building: Educational studies in Legitimation Code Theory (pp. 233-243). London, England: Routledge.

Maton, K. (in press). Semantics from Legitimation Code Theory: How context-dependence an complexity shape academic discourse. In J. R. Martin, K. Maton, P. Wang, \& Z. Wang (Eds.), Understanding academic discourse. Beijing, China: Higher Education Press.

Maton, K., \& Chen, R. T.-H. (2016). LCT in qualitative research: Creating a translation device for studying constructivist pedagogy. In K. Maton, S. Hood, \& S. Shay (Eds.), Knowledge-building: Educational studies in Legitimation Code Theory (pp. 27-48). London, England: Routledge.

Maton, K., \& Doran, Y. (2017). SFL and code theory. In T. Bartlett \& G. O'Grady (Eds.), The Routledge systemic functional linguistic handbook. London, England: Routledge.

Matruglio, E., Maton, K., \& Martin, J. R. (2013). Time travel: The role of temporality in enabling semantic waves in secondary school teaching. Linguistics and Education, 24(1), 39-40. https://doi.org/10.1016/j.linged.2012.11.007

Rothery, J. (1994). Exploring literacy in school English (Write it right resources for literacy and learning). Sydney, Australia: Metropolitan East Disadvantaged Schools Program.

Szenes, E., Tilakaratna, N., \& Maton, K. (2015). The knowledge practices of critical thinking. In M. Davies \& R. Barnett (Eds.), The Palgrave handbook of critical thinking in higher education (pp. 573 591). New York, NY: Palgrave Macmillan. 